\title{
Conflitos no campo do saber: universidades, historiadores e usos do passado na fronteira - Londrina, 1970-1980
}

\section{Conflicts in the field of knowling: universities, historians and uses of the past on the border - Londrina, 1970-1980}

\author{
Gilmar Arruda* \\ Wander de Lara Proença**
}

\begin{abstract}
Resumo
Nos anos de 1970, assistiu-se à criação de instituições universitárias no interior do país. Entre as federais, foram criadas as universidades de Mato Grosso, de Mato Grosso do Sul, do Acre, de Rio Grande, entre outras. No âmbito estadual, surgiram no Paraná as de Londrina, Maringá, Cascavel e Ponta Grossa; na Bahia, a de Feira de Santana; a do Ceará, assim por diante. A partir disso, o objetivo deste artigo é investigar as relações que se estabeleceram entre a cidade e a instituição universidade, tendo como foco de análise o caso da cidade de Londrina (PR) e a Universidade Estadual de Londrina (UEL). Particularmente, examina-se como se estabeleceram as relações entre os campos de produção do conhecimento sobre o passado: por um lado, o já estabelecido na cidade, criado por memorialistas, cronistas, romancistas, jornalistas, murais e outros agentes; de outro lado, na instituição universidade, outro campo com suas regras próprias de produção do conhecimento. Os resultados da pesquisa evidenciam que o surgimento do curso superior de História, precursor da universidade, não representou quebra, ruptura ou tensão com o campo da "crônica", nem mesmo a primeira geração de professores atuantes nos anos de 1970, no âmbito da universidade, significou essa tensão. Ao contrário, a universidade teria sido uma ampliação do campo anterior, assimilando o novo espaço e mantendo as regras de poder já estabelecidas. Constata-se que somente na década de 1980 apareceram tensão e ruptura com o campo da "crônica".
\end{abstract}

Palavras-chave: Campo do saber; Universidade; Fronteira; Historiadores.

\footnotetext{
*Doutor em História. Professor do Departamento de História da Universidade Estadual de Londrina -CNPq. E-mail: garruda@uel.br

** Doutor em História. Professor do Departamento de História da Universidade Estadual de Londrina. E-mail: wander@uel.br. Parte das reflexões apresentadas neste artigo é resultado de um estágio de pós-doutorado em História na Universidade Federal do Rio Grande do Sul, sob supervisão do Prof. Dr. Jurandir Malerba
} 


\begin{abstract}
The 1970s saw the creation of universities (states and federal) in the interior of the country. The federal universities like those of Mato Grosso, Mato Grosso do Sul, Acre and Rio Grande among others. At the state level, in Paraná there are that of Londrina, Maringá, Cascavel, Ponta Grossa; in the Bahia state, Feira de Santana. The aim of this paper is to investigate the relationships that have been established between the city and the university institution, focusing on the case of the city of Londrina - PR and the State University of Londrina - UEL. In particular, it is interesting to examine how the production of knowledge about the past, historiography, in the university institution, with its own rules of knowledge production and the establishment of 'fields of knowledge', dialogued with the field of knowledge about the past already established in the city., through memorialists, chroniclers, novelists, journalists, murals and other agents.
\end{abstract}

Keywords: Field of knowledge; University; Frontier; Historians.

\title{
Introdução
}

Nos anos de 1970, a criação de universidades - estaduais e federais no interior do Brasil, com respectiva oferta de cursos de História ${ }^{1}$, alterou o lugar de produção historiográfica, antes restrito a poucas instituições nos chamados grandes centros:

De 1971 até hoje, em pouco tempo, saímos de uma realidade de concentração de formação de historiadores e de produção historiográfica em um número restrito de instituições de ensino superior e estados da federação para uma cobertura nacional, tanto no mestrado acadêmico como no doutorado. [...] Hoje, a produção histórica brasileira é mais diversificada e menos concentrada em poucas instituições. ${ }^{2}$

\footnotetext{
${ }^{1}$ Nos anos de 1970, entre as federais, por exemplo, foram criadas as universidades de Mato Grosso, Mato Grosso do Sul e Rio Grande (RS). No âmbito estadual, surgiram, no Paraná, as de Londrina, Maringá e Ponta Grossa; na Bahia, a de Feira de Santana; também a do Ceará, entre outras.

${ }^{2}$ Os autores comparam dados: "Em 2018, quando escrevemos, apenas cinco estados da federação ainda não possuem mestrado acadêmico em História, todos na região Norte (Acre, Amapá, Rondônia, Roraima e Tocantins)". (FICO, Carlos; WASSERMAN, Claudia; MAGALHÃES, Marcelo de Souza. Expansão e avaliação da área de história: 2010-2016. História da Historiografia, Ouro Preto, v. 11, n. 28, p. 267-302, set./dez. 2018. Disponível em: https://www.historiadahistoriografia.com.br/revista/issue/view/31. Acesso em: abr. 2020).
} 
Considerando essa "interiorização do ensino superior", o presente artigo analisa como a historiografia, na instituição universidade - com suas regras próprias, representante da história crítica, documentada e teoricamente fundamentada -, dialogou com saberes já produzidos sobre o passado de autoria de cronistas, memorialistas, romancistas, jornalistas e outros agentes, em uma cidade localizada na fronteira ${ }^{4}$.

Essa elaboração, no sentido amplo, que surge fora da academia ou que a ela precede, é nominada de diversas maneiras ${ }^{5}$, entendida, por exemplo, como "[...] não profissional, produzida por intelectuais autodidatas com as mais diversas formações [...]"6. Trata-se de um saber vinculado, por vezes, ao poder de mando, derivado de uma elite local, que constrói, veicula, valida e, principalmente, legitima os usos políticos sobre os sentidos e as interpretações desse passado. Em Londrina (PR), contexto em análise aqui,

[...] desde os relatos desses primeiros colonizadores, foi se construindo, por meio de crônicas, álbuns e demais publicações comemorativas e alusivas à colonização, uma história que se pretende oficial, a qual se tornou hegemônica por muitas décadas consagrando como mitos fundadores de Londrina, a Companhia de Terras Norte do Paraná e os bravos pioneiros?

Nessa cidade, portanto, os espaços e os agentes são os jornais, as revistas, os murais, os jornalistas, os cronistas etc. Contudo, também existe um ponto de articulação, que, de certa forma, encontra-se no meio, entre o campo de saber da cidade - aqui chamado de "crônica" - e o do mundo da universidade - chamado aqui de "historiografia": a Faculdade Estadual de

\footnotetext{
${ }^{3}$ Expressão empregada por: FICO, Carlos; POLITO, Ronald. A história no Brasil - elementos para uma avaliação historiográfica. Ouro Preto: UFOP, 1992, p. 142.

${ }^{4}$ Sandra Jatahy Pesavento (2002) comenta que há uma tendência de se pensar a fronteira a partir de uma concepção ancorada na territorialidade, que se desdobra no âmbito político. Nesse sentido, é entendida, sobretudo, como encerramento de um espaço, delimitação de um território, fixação de uma superfície, um marco que limita e separa. Todavia, enquanto conceito impregnado de mobilidade, supera seus limites geopolíticos para assumir outros marcos e representações de dimensão simbólica, com sentidos socializados de reconhecimento que sofrem as transformações do tempo. Cf. PESAVENTO, Sandra Jatahy. Além das fronteiras. In: MARTINS, Maria Helena (Org.). Fronteiras culturais. Brasil-Uruguai-Argentina. São Paulo: Ateliê Editorial, 2002, p. 35-36.

${ }^{5}$ Jurandir Malerba aponta diversas terminologias empregadas para distinguir os chamados "historiadores práticos" dos "acadêmicos": escritores de história, historiadores populares, historiadores leigos. Cf. MALERBA, Jurandir. Notas à margem. Teoria e crítica historiográfica. Serra (ES): Editora Milfontes, 2018, p. 129 .

${ }^{6}$ MALERBA, Jurandir. A história na América Latina. Ensaio de crítica historiográfica. Rio de Janeiro: FGV, 2009 , p. 17.

${ }^{7}$ LEME, Edson José Holtz. O teatro da memória: o Museu Histórico de Londrina - 1959-2000. 2013. Tese (Doutorado em História) - Universidade Estadual Paulista, Faculdade de Filosofia Júlio de Mesquita Filho, Ciências e Letras de Assis, 2013, p. 230.
} 
Filosofia, Ciências e Letras (FEFCLL), criada em $1956^{\circ}$ e que, a partir de 1971, passaria a integrar a Universidade Estadual de Londrina?.

Embora fosse uma instituição de formação de nível superior, inicialmente, a UEL não representava um lugar de produção intelectual nos moldes que viriam a ser configurados após os anos de 1970, com a criação do sistema de pós-graduação no Brasil, somada a outros fatores que serão analisados ao longo deste texto.

Em uma hipótese preliminar, estabeleceu-se que o surgimento da instituição de ensino superior, com suas regras próprias de produção de campo de saberes, com a lógica científica de demonstração e com a validação por pares teria produzido de imediato um novo campo de saber, o qual resultou em conflitos em relação ao passado estabelecido por outras lógicas de poder, como o poder político local ${ }^{10}$.

Porém, ao se aprofundar a investigação, em particular com as fontes orais, percebeu-se que a hipótese mais factível seria a de que o novo campo de saber produzido no ambiente universitário não surgiu de forma "abstrata", mas a partir de uma assimilação interativa com o já estabelecido campo da "crônica", muito mais amplo que simplesmente uma leitura sobre o passado da cidade.

Esse campo envolve um conjunto de produções e de percepções que remetem ao sentido de identidade de um determinado grupo social dominante. Então, faz-se necessário examinar o processo de constituição da Universidade na cidade e, em particular, o do próprio campo a ser examinado: da História. Além disso, intenta-se averiguar as transformações dentro desse campo, pois,

\footnotetext{
${ }^{8}$ A FEFCLL foi criada em Londrina pelo Decreto Estadual n 2568-A, de 25 de janeiro de 1956. Suas atividades foram iniciadas somente no ano de 1958, com a oferta de quatro cursos, noturnos: História, Geografia, Letras Neolatinas e Letras Anglo-Germânicas. Em seguida, na cidade, foram criadas outras faculdades: Faculdade Estadual de Direito de Londrina (1956); Faculdade Estadual de Odontologia de Londrina (1962); Faculdade Estadual de Ciências Econômicas e Contábeis de Londrina (1966); Faculdade de Medicina do Paraná (1967). Cf. LIMA, Enezila de. O ensino superior em Londrina. Boletim Informativo do Centro de Letras e Ciências Humanas, UEL, Londrina, p. 4-22, 1992; CESAR, Zenite Terezinha Ribas. $O$ ensino superior em Londrina. Semina, v. 10, n. 3, p. 182-186, 1989.

${ }^{9}$ A Universidade Estadual de Londrina (UEL) foi criada pelo Decreto no 18.110 , de 28 de janeiro de 1970. Reconhecida um ano depois, agrupou todos os cursos das cinco faculdades isoladas já existentes na cidade, passando a oferecer um total de treze cursos. Cf. LEME, op. cit., p. 164-165; Disponível também em: http:// portal.uel.br/conheca-a-uel/. Acesso em: abr. 2020.

${ }^{10}$ Projeto intitulado "A historiografia no Paraná (1970-2012) - os historiadores, seus lugares e suas regiões", desenvolvido de 2012 a 2015, na Universidade Estadual de Londrina, vinculado ao Conselho Nacional de Desenvolvimento Científico e Tecnológico (CNPq). Cf. ARRUDA, Gilmar; PROENÇA, Wander de Lara. A historiografia do Paraná e o espaço simbólico da academia: os historiadores, seus lugares e suas regiões (1970-2012). Revista de História Regional, UEPG/DHIS/PPGH, v. 18, n. 1, p. 240-260, 2013. Disponível em: http://www.revistas2.uepg.br/index.php/rhr. Acesso em: abr. 2020.
} 
na origem da universidade, no início da década de 1970, as regras e as posições dos agentes acompanhavam e defendiam as formas de interpretação do passado da cidade a partir do campo dos cronistas.

A interpretação desse passado estabelecida pela "crônica" continua presente e influenciando políticas públicas de memória, mesmo após décadas sendo profundamente criticada pelo novo campo do saber, o da universidade. Tornou-se, assim, ponto de resistência e de conflito.

\section{O campo de saber estabelecido: "cronistas"}

Pierre Bourdieu conceitua campo, em seu sentido amplo, como o espaço relativamente autônomo, com regras, lógicas e necessidades específicas ${ }^{11}$, onde se manifestam as relações de poder, as quais se materializam pela prática dos agentes:

[...] campo [é] o universo no qual estão inseridos os agentes e as instituições que produzem, reproduzem ou difundem a arte, a literatura ou a ciência. [...] A noção de campo está aí para designar esse espaço relativamente autônomo, esse microcosmo dotado de suas leis próprias ${ }^{12}$.

O autor aponta perspectivas para a compreensão da dinâmica que envolve a constituição do campo. É preciso, então, superar a polarização que estabelece uma relação direta entre o conteúdo de uma produção e o contexto: "Minha hipótese consiste em supor que entre esses dois polos, muito distanciados [...], existe um universo intermediário que chamo o campo literário, artístico, jurídico ou científico" ${ }^{13}$.

Uma análise com o emprego do conceito de campo, segundo Bourdieu, implica três aspectos inter-relacionados: a posição do campo específico em relação ao campo do poder; a estrutura objetiva das relações e as posições ocupadas - por agentes e instituições - que competem no interior do campo; os diferentes sistemas de posições que os agentes adquiriram em uma trajetória definida dentro do campo considerado ${ }^{14}$.

Mais especificamente em relação aos campos disciplinares, Louis Pinto comenta que "[...] a instituição universitária parece ter conseguido

\footnotetext{
${ }^{11}$ LAHIRE, Bernard. Campo. In: CATANI, Afrânio Mendes et al. (Orgs.). Vocabulário Bourdieu. Belo Horizonte: Autêntica, 2017, p. 64.

${ }^{12}$ BOURDIEU, Pierre. Os usos sociais da ciência: por uma sociologia do campo científico. São Paulo: Editora Unesp, 2003, p. 20.

${ }^{13}$ Ibidem.

${ }^{14}$ Cf. CATANI, Afrânio Mendes. Campo universitário. In: CATANI et al., op. cit., p. 96.
} 
monopolizar, não só a formação" - aqui, no caso, dos historiadores -, mas também o "percurso de suas carreiras, [...] a definição dos programas, a lista dos autores canônicos, o conteúdo e a forma dos exercícios escolares (dissertação e tese)", definindo, assim, uma fronteira demarcatória com interesses e objetos próprios, além de saberes distintos do senso comum ${ }^{15}$.

São esses elementos que tornam o campo disciplinar mediado por regras e definições de espaços: "[...] é a estrutura das relações objetivas entre os agentes que orienta o que eles podem e não podem fazer". Tais "princípios do campo" "comanda[m] os pontos de vista [...], as intervenções científicas, os lugares de publicação, os temas que escolhemos, os objetos pelos quais nos interessamos etc." 16

Christophe Charle ${ }^{17}$, ao comentar sobre o campo intelectual, chama a atenção para uma vereda a partir da concepção de Bourdieu em relação ao campo intelectual, conceituando-o em uma perspectiva sociológica e aplicando-lhe, a partir de Max Weber, dimensões simbólicas de outros espaços, como o campo religioso e o campo artístico.

Com isso, Bourdieu trata "[...] de romper com uma sociologia que estabelece uma relação direta entre interesse de classe, por um lado e, por outro, orientações ideológicas e intelectuais", ou seja, “[...] questiona a tradição letrada, idealista e intelectualista, dominante desde sempre nos estudos desses temas, que limita a interpretação dos conflitos intelectuais a um conflito de ideias puras, autônoma em relação aos contextos mais amplos"18. Tal questionamento possibilita ponderar: "[...] qual a margem de liberdade à disposição desse campo intelectual em relação ao campo do poder, ao campo econômico, ao campo religioso etc.? Em que sentido evolui essa margem, segundo as conjunturas históricas?"19

Essa perspectiva apontada sobre um "universo intermediário", de acordo com Bourdieu, permite superar as linhas demarcatórias pressupostas em polos que separam, de um lado, o que seria específico do mundo intelectual; de outro, o contexto mais amplo em que se circunscreve o campo. Esse viés de análise é bastante fértil para a compreensão do processo que envolveu

\footnotetext{
${ }^{15}$ PINTO, Louis. Campo filosófico. In: CATANI et al., op. cit., p. 82.

${ }^{16}$ BOURDIEU, 2003. op. cit., p. 23.

${ }^{17}$ Para ampliação da análise sobre os campos disciplinares, a história das universidades e dos intelectuais, assim como o conjunto de determinantes do trabalho científico e suas condições de controle, ver: CHARLE, Chistophe. Homo historicus. Reflexões sobre a história, os historiadores e as ciências sociais. Rio de Janeiro; Porto Alegre: FGV; Editora da UFRGS, 2018.
}

${ }^{18}$ CHARLE, Chistophe. Campo intelectual. In: CATANI et al. op. cit., p. 83-84.

${ }^{19}$ Ibidem. 
as produções do saber na região da fronteira aqui em análise, visto que esse novo campo de "autonomização intelectual" não está descolado do mundo à sua volta.

Em Londrina, nas décadas que antecedem a presença da universidade e, por conseguinte, a formação de um campo acadêmico historiográfico, já havia sido elaborado um saber sobre o passado da região, conexo ao campo do poder, de autoria de profissionais de diferentes áreas, como jornalistas, geógrafos, cronistas, publicado em revistas, jornais, murais ${ }^{20}$ ou encartes comemorativos $^{21}$, especialmente “[...] durante as décadas de 1950 e 1960"22. 0 campo do poder ${ }^{23}$ - que tem como peculiaridade a imposição do princípio legítimo de dominação, sendo irreconhecível enquanto arbitrário - matiza os

\footnotetext{
${ }^{20}$ Por ocasião das celebrações dos 25 anos e do cinquentenário do município de Londrina, respectivamente em 1959 e 1984, houve a fixação de murais em azulejos, erigidos como monumentos em locais públicos e com ampla circulação. Esses suportes têm como material de exposição as fotografias de José Juliani - fotógrafo que atuou profissionalmente a serviço da propaganda publicitária da Companhia colonizadora do norte paranaense, nas décadas de 1930 e 1940. Cf. ARRUDA, Gilmar. Monumentos, semióforos e natureza nas fronteiras. In: ARRUDA, Gilmar (Org.). Natureza, fronteiras e territórios. Londrina: Eduel, 2005, p. 1-42.

${ }^{21}$ Entre os livros celebrativos publicados como versões "oficiais" da história de Londrina e que buscaram construir uma identidade histórica para a cidade, destacam-se: 1) "Londrina: Estado do Paraná - 25 anos de sua História. Jubileu de Prata". São Paulo: Edigraf, 1959, de autoria de Humberto Puiggari Coutinho. Nele, o autor buscou reafirmar a grandiosidade de Londrina a partir da história de sua colonização. Coutinho foi diretor do jornal Paraná Norte, periódico financiado pela Companhia de Terras Norte do Paraná (CTNP) e porta-voz dela. 2) "Londrina no seu Jubileu de Prata: documentário histórico". Londrina: Realizações Brasileiras, 1960, de autoria dos jornalistas Gustavo Branco e Fideli Mioni. Contou com o apoio do jornal Folha de Londrina, principal jornal da cidade, para divulgação. A obra teve o auxílio de uma redatora, Honorina Borges de Andrade Chaves, que exercia o cargo de Oficial de Gabinete da Prefeitura à época, na gestão de Milton Menezes, e continuou a exercê-lo na administração de Fernandes Sobrinho. Gustavo Branco também era proprietário da revista Realizações Brasileiras e tinha prestígio junto às elites cafeeiras da cidade. Cf. CASTRO, Rosemeire A. Angelini. O cotidiano e a cidade: práticas, papéis e representações femininas em Londrina (1930-1960). 1994. Dissertação (Mestrado em História) - Universidade Federal do Paraná, Curitiba, 1994, p. 49; LEME, op. cit.

${ }^{22}$ Dentre os diversos álbuns e publicações comemorativos, que reforçam o ideário de uma história tradicional ou "oficial", destacam-se: ALMEIDA, Gladstone H. Guia Geral de Londrina. Londrina: Empresa Propagandística do Norte do Paraná, 1945; BARROSO, Vicente. O famoso Norte do Paraná: terra onde se anda sobre dinheiro. Caxias do Sul: Editora São Miguel, 1956; BRANCO, Gustavo; ANASTÁCIO, Adão. Construtores do progresso. Londrina: s/ed., 1969; CARVALHO, Brasilino. Londrina monumental: milagre do gênio britânico e do caboclo vencendo as forças brutas da natureza. São Paulo: Bipa, 1978; Companhia Melhoramentos Norte do Paraná. Colonização e desenvolvimento do Norte do Paraná: publicação comemorativa do cinquentenário da Companhia Melhoramentos Norte do Paraná. São Paulo: Companhia Melhoramentos Norte do Paraná, 1975; ELIAS, Jorge; MASCHIO, Edison. Documentário de Londrina. Curitiba: Gazeta do Paraná, 1977; ZORTÉA, Alberto João. Londrina através dos tempos e crônicas da vida. Edição comemorativa do $40^{\circ}$ aniversário. São Paulo: Juriscredi, 1975.

${ }^{23}$ Pode ser definido, a partir de Pierre Bourdieu, como "[...] o espaço em que se estabelece o valor relativo dos diferentes tipos de capitais que proporcionam um poder sobre o funcionamento dos diferentes campos". A expressão "campo do poder" pode ser usada como sinônimo de "classe dominante". Esse poder "[...] tem necessidade de ser legitimado, de se tornar irreconhecível enquanto arbitrário para se perpetuar" (DENORD, François. Campo do poder. In: CATANI, Afrânio Mendes et al., op. cit., p. 75-76).
} 
saberes produzidos, legitimando interesses políticos, vinculados ao mando de elites locais:

As publicações, tanto particulares quanto aquelas produzidas pelo poder público municipal, crônicas, livros-documentários e notadamente os álbuns comemorativos, elegeram, para serem os protagonistas dessa história, apenas os representantes dos grupos hegemônicos da sociedade, tornados vultos e nomes tutelares da história local/regional. Os segmentos populares, quando apareciam, ocupavam um espaço discreto de coadjuvantes anônimos, figurantes mudos da grande epopeia pioneira. ${ }^{24}$

Essa produção de cronistas, assim como ocorre no âmbito da academia, possui suas regras de validação, de reconhecimento e de controle. "Qualquer imaginário se sustenta historicamente na identificação de certos grupos sociais em relação ao sistema simbólico que representa, feedback sem o qual seria silenciado ou mesmo desapareceria" ${ }^{25}$. A monumentalização de murais de fotografias ${ }^{26}$, expostos publicamente como semióforos, exemplifica como isso ocorre ${ }^{27}$ :

[...] a interpretação, ou a aceitação da interpretação contidas naquelas imagens [...] só foram realizadas daquela forma porque passaram por uma espécie de aval do sentido coletivo sobre o que aconteceu e o que estava acontecendo. 0 aval articula o passado do observador, seu presente e suas expectativas com relação ao futuro $[\ldots] .^{28}$

A consagração de uma dada narrativa sobre o passado, portanto, não deve ser atribuída à "genialidade" do narrador ou do agente, mas, sim, ao sentido coletivo; o poder de consagração reside não no indivíduo isolado, mas no universo de crenças ou de expectativas dispostas no campo. Bourdieu fundamenta melhor isso quando afirma que "[...] o capital simbólico é uma propriedade que, percebida pelos agentes sociais dotados das categorias de

\footnotetext{
${ }^{24}$ LEME, op. cit., p. 24.

${ }^{25}$ ANDRÉ, Richard G. 0 paraíso entre luzes e sombras: representações de natureza em fontes fotográficas (Londrina, 1934-1944). Londrina: Eduel, 2014, p. 171.

${ }^{26} \mathrm{Na}$ cidade de Londrina, foram realizados dois murais com a ampliação de fotografias consideradas históricas, o primeiro construído em 1959, como parte das comemorações do $25^{\circ}$ aniversário da cidade; o segundo, de 1984, no seu cinquentenário. Cf. ARRUDA, op. cit.

${ }^{27}$ Termo usado para definir objetos, pessoas ou instituições colocados em evidência pelos seus significados de comunicação e pela produção de sentidos, expostos ao olhar para articular o visível e o invisível, o passado e o presente. Cf. Ibidem, p. 1, 2, 8 .
}

${ }^{28}$ Ibidem, p. 15. 
percepção e de avaliação", torna-se simbolicamente eficiente “[...] por responder às expectativas coletivas, socialmente construídas" 29 .

Esses bens simbólicos produzidos pelo memorialismo, "[...] a despeito do silêncio em relação a diferentes recordações e visões do processo histórico" ${ }^{30}$, são coletivamente controlados ou resguardados pelos agentes produtores:

Entre os signos de poder e de prestígio estão os elementos da história, as narrativas que enaltecem os feitos dos grandes homens do passado, os trabalhos e a luta em torno da memória. [...] Nesse sentido, tornar-se os "senhores da memória”, ou estar mais perto da fundação dos fundadores, é um recurso importante na constituição de poder e legitimidade. ${ }^{31}$

Isso ocorre, por exemplo, quando tais materiais são reunidos em acervos nos centros de documentação, nos museus ou nos lugares de memória.

Em balanço historiográfico sobre as obras do campo da "crônica", Sônia Adum identifica algumas de suas características e perspectivas ${ }^{32}$. Primeiro, são portadoras de um "discurso de felicidade", são textos produzidos ao longo das décadas de 1930, 1940, 1950, 1960, os quais, "apesar da diversidade de gênero, tema e estilo, podem ser caracterizados como de "exaltação"'33. Ademais, ela comenta: "Na perspectiva dessas obras, o norte do Paraná é a Terra da Promissão, o Eldorado, a nova Canaã, o paraíso prometido da fertilidade, da produção agrícola abundante, das oportunidades iguais de enriquecimento para todos aqueles que quisessem trabalhar e prosperar" ${ }^{34}$.

Segundo, "[...] uma narrativa paralela, que pode até ser caracterizada como marginal, emerge já nos anos 1950"35, apresentando, como contrapartida ao "discurso de felicidade", a constatação da violência visibilizada na luta diária dos grupos marginalizados - jogadores, prostitutas, cáftens, ladrões, vagabundos -, os quais apareciam retratados nas páginas policiais dos jornais. Conforme Adum, “Tais abordagens propiciaram a presença, no cenário

\footnotetext{
${ }^{29}$ BOURDIEU, Pierre. Razões práticas. Sobre a teoria da ação. Campinas: Papirus, 1996, p. 177.

${ }^{30}$ ANDRÉ, op. cit., p. 171.

${ }^{31}$ ARRUDA, op. cit., p. 9.

${ }^{32}$ ADUM, Sonia M. Esperandio Lopes. Historiografia norte paranaense: alguns apontamentos. In: ALEGRO, Regina Célia et al. (Orgs.). Temas e questões para o ensino de história do Paraná. Londrina: Eduel, 2008.

${ }^{33}$ São exemplos: publicações da própria Companhia colonizadora, álbuns comemorativos e crônicas produzidas sobre a região.

${ }^{34}$ ADUM, op. cit., p. 4.

${ }^{35}$ Ibidem, p. 8.
} 
dessa história, de outros personagens que, já bem cedo, fizeram sua estreia, desnudando o outro lado da "civilização"'36.

Já em terceiro está a visão dos estrangeiros, a partir de dois intelectuais franceses: o geógrafo Pierre Monbeig e o antropólogo Claude Lévi-Strauss, que vieram ao Brasil para atuarem na Universidade de São Paulo37: "Após viajarem pela região norte do Paraná na década de 1930, desenvolveram importantes reflexões acerca desse espaço e acabaram por influenciar, sobremaneira, os escritos posteriores, sobretudo os produzidos na academia" ${ }^{38}$.

Por fim, "[...] as novas histórias, produzidas na academia", no final dos anos 1980, representam uma "virada", visto que "[...] alguns campos novos passaram a ser explorados", conforme destacado por Sonia Adum:

De meados para o final dos anos 1980, a historiografia sobre Londrina e região foi sacudida por um significativo desenvolvimento quantitativo e qualitativo, iniciando-se uma releitura da história local e regional, que buscou, por um lado, desvencilhar-se da preocupação com o conceito de região, procurando inserir as análises em uma perspectiva de história nacional e, por outro, estabelecer uma relação mais crítica a respeito do processo de colonização e seus atores. ${ }^{39}$

Esses aspectos de "mudança" e os conflitos decorrentes disso serão abordados no próximo item, a partir da presença da instituição universitária no campo e da atuação dos primeiros historiadores a ela vinculados.

\section{Os saberes sobre o passado no ambiente da universidade: historiografia}

O surgimento de cursos superiores no interior do país, dentre outros fatores, tem relação com a política nacional-desenvolvimentista dos anos 1950, do governo Juscelino Kubitschek, que gerou demanda por maior qualificação

\footnotetext{
${ }^{36}$ Adum comenta que um pouco de cada um desses dois primeiros gêneros reaparecerá nas histórias produzidas posteriormente. "Os da primeira categoria, de 'exaltação', voltarão naquelas que mostram a vitalidade do povoamento e o progresso que se instaura; os da segunda, 'marginal', naquelas histórias que farão emergir os segmentos populares, que deixarão de ocupar o espaço discreto de coadjuvantes para se transformarem nos personagens centrais dos relatos" (Ibidem, p. 8-9).

${ }^{37}$ Pierre Monbeig, nos anos 1930 e 1940, publicou artigos em revistas especializadas, como por exemplo: MONBEIG, Pierre. A zona pioneira do norte do Paraná. Revista Brasileira de Geografia [S.I], ano I, n. 3, 1935. Neles, "[...] observou o desenvolvimento da franja pioneira paulista, que posteriormente se estendeu ao Paraná, e percebeu a lógica norteadora da ação das várias companhias privadas de colonização". LéviStrauss, em sua obra Tristes Trópicos (Cf. LÉVI-STRAUSS, Claude. Tristes Trópicos. Lisboa, São Paulo: Edições 70, Companhia das Letras, 1996), refere-se "[...] ao projeto de colonização que se iniciava no norte do Paraná sob a direção da Cia. Inglesa, tendo também observado o aspecto da racionalidade e do planejamento nesta frente pioneira". Cf. ADUM, op. cit., p. 10.

${ }^{38}$ Ibidem, p. 10.

${ }^{39}$ ADUM, op. cit., p. 13.
} 
e especialização de mão de obra para atender à estruturação da indústria de base e das obras de infraestrutura. "Estes fatores geraram uma necessidade social pela conquista do diploma universitário, não só por uma inserção melhor remunerada no mercado de trabalho, como também pelo status que ele representava na sociedade" 40 .

O crescimento econômico de Londrina, na década de 1950, está associado a esse quadro mais amplo. Soma-se a isso a necessidade de maior qualificação de docentes para "darem conta" da demanda crescente de abertura de escolas. A não existência de cursos superiores na região "[...] obrigava os jovens da cidade, em busca de capacitação profissional”, a se "[...] mudarem para outros centros como São Paulo e Curitiba"41. Tal cenário e a mobilização de lideranças políticas e de educadores resultaram, como anteriormente mencionado, na criação oficial, em 1956, da primeira instituição de nível superior de Londrina.

A presença da instituição de ensino superior ${ }^{42}$ no contexto da cidade trouxe como elemento novo a emergência de um campo intelectual, sendo assim, a possibilidade de autonomização da produção acadêmica. O campo intelectual, por sua vez, é regido por regras que comandam os pontos de vista, sendo caracterizado por posições, prestígio, autoridade e obtenção de insígnias acadêmicas, derivados do capital de conhecimento acumulado ${ }^{43}$.

O Homo academicus ${ }^{44}$, desse modo, deve ser situado na dinâmica social dos jogos de interesses epistemológicos e políticos, nas relações de força e nas estratégias concorrenciais ${ }^{45}$, pois o campo intelectual se constitui como "[...] espaço de jogo de uma luta concorrencial", hospedando tensões entre os produtores tradicionais e os acadêmicos, entre os discursos já postos e

\footnotetext{
${ }^{40}$ LIMA, op. cit., p. 9.

${ }^{41}$ Ibidem, p. 15.

${ }^{42}$ Segundo Bourdieu, o campo universitário se refere ao poder institucional acumulado como capital e também à ocupação dos postos administrativos mais importantes no âmbito do ensino superior. Pode ser conceitualmente definido, ainda, como espaço social onde se trava uma luta concorrencial para estabelecimento do monopólio legítimo do saber acadêmico ou universitário, ou seja, uma produção consagrada e legitimada; como um locus que tem como protagonistas agentes investidos da delegação para gerir e produzir políticas universitárias. Exemplificam os diferentes tipos de capital que compõem o campo universitário: escolas que os indivíduos frequentam, títulos obtidos, premiações, projetos de pesquisa desenvolvidos, pertencimento a comitês editoriais de revistas científicas, publicações relevantes, currículos, orientações acadêmicas etc. Cf. CATANI, A. M. Campo universitário. In: CATANI et al. op. cit., p. 96-97.

${ }^{43}$ BOURDIEU, 2003, op. cit., p. 26.

${ }^{44}$ Título de um dos principais livros de Bourdieu, dedicado ao estudo do campo universitário francês. Cf. BOURDIEU, Pierre. Homo academicus. 2. ed. Florianópolis: UFSC, 2013.

${ }^{45}$ BOURDIEU, Pierre. Campo científico. In: ORTIZ, Renato (Org.). Bourdieu - Sociologia. São Paulo: Ática, 1983, p. 122.
} 
aqueles que representam mudanças ${ }^{46}$ : "todo campo é um campo de forças e um campo de lutas para conservar ou transformar esse campo de forças" ${ }^{47}$.

Esse embate se processa dualizando dominantes (agentes que configuram a geração detentora do capital) e os dominados (os novatos). Os dominantes utilizam as estratégias de conservação; e os novatos, em hipótese, adotam as estratégias de subversão. Os novatos, então, podem escolher dois caminhos: adotar as estratégias de sucessão em conformidade e continuidade com a lógica imposta pelos dominantes; ou seguir as estratégias de subversão que rompem com os princípios vigentes, intentando redefinir a lógica do modelo estabelecido ${ }^{48}$.

A formação do campo intelectual e a respectiva criação do curso de História, no contexto em que estava estabelecido o saber da "crônica", requerem a problematização de alguns tópicos, expostos a seguir.

1) A presença do campo historiográfico teria possibilitado ao campo da "crônica" ampliar seu poder e seu espaço. Em princípio, as noções conceituais pressupõem que um campo se constitui na medida em que entra na disputa por uma autonomia em relação a outros campos, sendo a autonomização do campo intelectual, no caso, marcada por conflitos com os agentes não revestidos daquelas insígnias do mundo da universidade.

Assim, era de se esperar que o estabelecimento da instituição universitária na fronteira gerasse subversões e confrontos pela luta concorrencial do espaço em que já estavam fixadas narrativas atreladas ao campo do poder. Em outras palavras, as tensões produzidas pela criação do curso de História seriam a evidência da autonomização e do estabelecimento do campo intelectual. Entretanto, ao menos de início, essa evidência não se efetivou, visto que a instituição de ensino superior, desde a sua criação no final dos anos de 1950 até meados de 1980, ampliou o estatuto e a validade daquela interpretação já estabelecida.

De modo mais específico, podem ser apontados como principais vetores que contribuíram diretamente para isso: o quadro inicial de docentes da Faculdade e a criação do Museu Histórico. Sobre os docentes, provinham do ensino de $1^{\circ}$ e $2^{\circ}$ graus em que atuavam, sendo que a maioria não era formada em História: "Naquele período, na FEFCLL, dentre os docentes que ministravam aulas para o curso de História havia advogados, padre e um agrimensor" ${ }^{49}$.

\footnotetext{
${ }^{46}$ BOURDIEU, 2003. op. cit., p. $28-29$.

${ }^{47}$ Ibidem, p. 22.

${ }^{48}$ BOURDIEU, Pierre. Campo científico. In: ORTIZ, Renato, op. cit, p. 139.

${ }^{49}$ Segundo depoimentos de ex-alunos do curso: Jorge Cernev e José Cezar dos Reis. (LEME, op. cit., p. 129).
} 


\section{Em depoimento, Enezila de Lima ${ }^{50}$, ex-aluna do curso de História (1964-1967), da antiga FEFCLL, declara que:}

[...] os docentes na época eram apenas graduados. Desses, poucos tinham formação em História. A estrutura curricular na então Faculdade estava direcionada às atividades pedagógicas, já que o objetivo primeiro era a formação de docentes. A pesquisa não tinha espaço. Com relação ao trabalho com fontes históricas, a exceção [...] era a professora Maria Dulce Gotti, que, devido a uma rápida passagem pela Universidade de São Paulo, fazia um trabalho com fontes em sua disciplina de Introdução aos Estudos Históricos. ${ }^{51}$

\section{Em sua primeira fase, emergiram no ambiente da Faculdade propos-} tas para que as interpretações realizadas no campo de saber da crônica se tornassem a interpretação predominante da cidade. Isso se deu com a criação do Museu Histórico de Londrina ${ }^{52}$, o qual surgiu para ser depositário da memória local ${ }^{53}$. Ademais, foi constituído pela iniciativa de professores da antiga Faculdade de História, sendo gestado nas salas de aula do curso, na segunda metade dos anos de $1960^{54}$. Coube também a esses docentes o papel

\footnotetext{
${ }^{50}$ Docente aposentada do Departamento de História da UEL.

${ }^{51}$ Depoimento de Enezila de Lima [apud MAESIMA, Cacilda. Centros de Documentação e Pesquisa Histórica Universitários: um estudo de caso no CDPH da UEL. 2003. Dissertação (Mestrado em História) - Universidade Federal Fluminense, Niterói-RJ, 2003, p. 85].

${ }^{52}$ Inaugurado em 18 de setembro de 1970. Sua criação coincide com o período em que foi gestada a Universidade Estadual da cidade.

${ }^{53}$ Martinez argumenta, com base nas estatísticas das peças recolhidas lançadas no primeiro livro de registro, que, no momento inicial da constituição desse Museu, na gestão do seu primeiro diretor, Pe. Carlos Weiss, a prioridade não teria sido a memória local ou regional, mas as questões arqueológica e etnológica. A inversão desse sentido só teria ocorrido posteriormente, nos anos de 1980, durante a gestão da Prof. ${ }^{a}$ Conceição Geraldo. (MARTINEZ, Cláudia Eliane P. Entre palavras e imagens: famílias negras no Museu Histórico de Londrina/PR. Revista de História Regional, UEPG/DHIS/PPGH, v. 23, n. 2, p. 321-343, 2018. Disponível em: http://www.revistas2.uepg.br/index.php/rhr. Acesso em: maio 2020). Entretanto, tanto Leme (op. cit.) como Hildebrando demonstram que, no surgimento dessa instituição, estava claro que compreendia um Museu e um Arquivo Histórico. (HILDEBRANDO, Gilberto. 0 museu e a escola: memórias e histórias em uma cidade de formação recente - Londrina/PR. 2010. Dissertação (Mestrado em História) - Universidade Estadual de Londrina, Londrina, 2010). Sobre isso, ver também SILVA, Taine Vanessa da. 0 trânsito entre o comum e o ilustre: a (re)ocupação do norte do Paraná e o registro de experiências narradas no Museu Histórico de Londrina, década de 1970. 2018. Dissertação (Mestrado em História) - Universidade Estadual de Londrina, Londrina, 2018.

${ }^{54} \mathrm{Em} 1974$, o Museu se tornou órgão suplementar da Universidade Estadual de Londrina (UEL) e, em 1978, recebeu o nome de Museu Histórico de Londrina "Pe. Carlos Weiss". A desativação da estação ferroviária na década de 1980 viabilizou o local, considerado favorito para a realocação do Museu Histórico de Londrina, de forma que, em 10 de dezembro de 1986, a transferência foi efetivada. Por conseguinte, o projeto intitulado "Memória Viva", ocorrido entre 1996 e 2000, foi responsável pela revitalização do prédio utilizado pelo MHL, com o intuito de reestruturá-lo a partir da construção de alas expositivas e da reorganização da exposição de longa duração. Cf. SILVA, op. cit., p. 27.
} 
decisivo na composição do acervo ${ }^{55}$, caracterizado pela identificação direta com a narrativa do memorialismo da cidade, marcado pela ideologia do pioneirismo e das elites locais:

Desde sua fundação, foi-se estruturando seu acervo a partir desta perspectiva tradicional da história da cidade. Esta formatação museológica contou, inicialmente, com o suporte acadêmico de professores do Departamento de História, da antiga Faculdade Estadual de Filosofia, Ciências e Letras (FEFCLL), os quais se identificavam com esta narrativa. ${ }^{56}$

A criação do Museu é a maior evidência de como o campo da crônica assimilou as novas regras do campo acadêmico/universitário, ampliando seu poder e seu espaço na cidade:

Ainda no final da década de 1960, priorizou em seu acervo objetos visando à formação de uma instituição museológica com caráter regional. o processo de colonização, a ocupação do território, o rápido desenvolvimento e crescimento urbano, e a ênfase no chamado pioneirismo, demarcaram não só a configuração do seu acervo, mas também, suas primeiras exposições. ${ }^{57}$

Essa relação interativa se consolidou ainda mais quando, pouco tempo depois, o Museu passou a ser órgão suplementar da Universidade Estadual de Londrina, vinculado academicamente ao Departamento de História, de onde também, por praxe, são escolhidos os seus diretores.

Em uma primeira aproximação, poderia-se afirmar que a formação mais tradicional, do ponto de vista historiográfico, por parte dos poucos historiadores docentes - fator aliado ao número de profissionais não graduados em História -, teria influenciado na elaboração do conceito de museu/arquivo histórico que se estava criando. Essa perspectiva tradicional de história refletiu na coleta de objetos e de documentos textuais de "valor histórico", com ênfase no ufanismo colonizador da região:

Visando a formação do acervo, os alunos do curso de História eram incentivados a buscar doações de peças e documentos em Londrina e nas suas cidades de origem e recebiam notas por este trabalho. Vários docentes do Departamento passaram a direcionar suas disciplinas, com o intuito de transformar em atividades acadêmicas esse processo de coleta de documentos e peças. Essa atividade tinha como objetivo abastecer o futuro museu e arquivo de acervos.

\footnotetext{
${ }^{55}$ Para formar o acervo do futuro museu, "[...] alunos e professores iniciaram, a partir de 1969, junto à comunidade, um movimento visando coletar peças, objetos e documentos relacionados à história da cidade e da região norte paranaense" (LEME, op. cit., p. 127).

${ }^{56}$ Ibidem, p. 24.

${ }^{57}$ LEME, op. cit., p. 179.
} 
A perspectiva adotada direcionava este processo de pesquisa e de coleta para questões relacionadas aos colonizadores da região. ${ }^{58}$

A Faculdade de História, portanto, por meio de seus docentes e do Museu Histórico da cidade, realizou um papel de chancela da "[...] narrativa de exaltação aos mitos fundadores", que acabou sendo "[...] reiterada e consolidada em livros didáticos" e perpetuada pelas visitas monitoradas àquele lugar de memória ${ }^{59}$. Desse modo, a instituição universitária foi instada, com sua expertise acadêmica, a referendar por meio do acervo e da narrativa museal o que já havia se estabelecido como conhecimento sobre o passado da região.

2) O lugar de produção em que se situam os agentes, assim como a formação "profissional" do historiador, não seriam determinantes do fazer historiográfico. Observa-se que há um descompasso conceitual sobre o que é produzido em relação à tipicidade do lugar de produção. A primeira "geração", vinculada à Faculdade e posteriormente à universidade, não era formada por leigos, mas tinha formação acadêmica ou superior, mesmo que não fosse na área de História.

Esses docentes possuíam uma perspectiva metodológica que pode ser identificada como "positivista" ou descritiva, como observado por Sonia Adum: "[...] nos anos 1980, os professores mais antigos eram denominados pelos docentes mais novos como positivistas" ${ }^{60}$. Por exemplo, Conceição Aparecida Duarte Geraldo - ex-aluna, posteriormente docente do Departamento de História da UEL, na disciplina de História da Arte, e diretora do Museu - e também Maria Dulce Alho Gotti - professora que fazia um trabalho com fontes em sua disciplina de Introdução aos Estudos Históricos, primeira diretora do Arquivo Histórico, localizado no porão do Grupo Escolar Hugo Simas - ${ }^{61}$ tinham informações sobre a metodologia da história oral ${ }^{62}$.

\footnotetext{
${ }^{58}$ Ibidem, p. 128.

${ }^{59}$ Ibidem, p. 24.

${ }^{60}$ ADUM, Sonia Sperandio Lopes. Entrevista concedida a Gilmar Arruda e Wander de Lara de Proença. Projeto de pesquisa intitulado: "A historiografia no Paraná (1970-2012) - os historiadores, seus lugares e suas regiões". Londrina, UEL, 2014.

${ }^{61}$ LEME, op. cit., p. 168.

${ }^{62}$ Olímpio Luiz Westphalen é outro nome que compõe esse grupo de docentes. Historiador, graduado em Geografia e História pela Faculdade de Filosofia, Ciências e Letras, na Universidade Federal do Paraná, era professor da rede estadual de ensino, em Londrina. Ele tornou-se um dos primeiros professores da Faculdade Estadual de Filosofia, Ciências e Letras, sendo também diretor do Museu Histórico por cinco anos. Olímpio, a partir de suas concepções de História, foi um dos defensores da narrativa do Museu em relação à chamada "história hegemônica" ou predominante da cidade, com ênfase nas figuras dos pioneiros, da CTNP e de personagens a ela vinculados.
} 
Em sua dissertação de mestrado em História, Taiane Vanessa da Silva cita um depoimento ${ }^{63}$ de Conceição: "Naquele tempo não havia ainda sido criada a história oral como uma atividade técnica"; mas, quando "[...] ainda tudo era feito na base da improvisação, a professora Maria Dulce começou esse trabalho de depoimentos orais", fazendo "[...] contato com pessoas ligadas a essa área da História, ligadas à história oral, na Universidade Federal do Paraná e na USP [Universidade de São Paulo]"64.

Assim sendo, observa-se que a recolha dos depoimentos não ocorrera de forma "amadora", mas chancelada pela experiência universitária de duas instituições de renome acadêmico. Então, recorrer a métodos do campo universitário significava, também, conferir ao trabalho realizado legitimidade, distinção e ampliação do poder. Em razão disso, seria mais acertado afirmar que não fora a falta de formação que levou, por exemplo, a organização do Museu a partir da perspectiva "ufanista do colonizador", mas, sim, a aderência dos envolvidos à própria concepção de passado nos moldes desse modelo de narrativa. Eles mesmos se consideravam pioneiros ou partilhavam desse processo.

Outras evidências dessa aderência à interpretação do passado com ênfase na memória do pioneirismo, na formação do Museu/Arquivo, são encontradas nas percepções de Conceição Geraldo - diretora daquela instituição em dois momentos significativos -, que foram analisadas por Taiane Vanessa da Silva em 2018. Em entrevista, Conceição ressalta: "Eu fui a primeira aluna a trazer as primeiras peças [fala com ênfase] com relatório [...]. Umas peças interessantes. Tinha da cultura indígena, tinha coisas de pioneiros de Uraí [sua cidade natal] [...] e outras coisas mais, que têm na relação. Então, eu fui a primeira aluna. Primeira" 65 . Silva observa que Conceição “[...] coloca a si mesma, neste e em vários momentos da entrevista, como peça importante na constituição da instituição, principalmente ao ressaltar [...] sua atuação pioneira na doação de objetos e documentos" 66 . Conforme observado por Pollak e citado por Silva, “[...] existem narrações de lembranças que se repe-

\footnotetext{
${ }^{63}$ Entrevista em arquivo no Núcleo de Documentação e Pesquisa Histórica (NDPH) da Universidade Estadual de Londrina, na qual Conceição Geraldo conta detalhes do início da produção de entrevistas do Museu e do Arquivo Histórico. "O depoimento foi conduzido, em 1989, por alunas da graduação em História da UEL vinculadas ao projeto Aparelhamento e organização do Núcleo de História Oral do Centro de Documentação e Pesquisa Histórica. A iniciativa visava organizar o acervo de fitas existentes no NDPH da UEL, para constituir um Núcleo de História Oral" (SILVA, op. cit., p. 24).

${ }^{64}$ SILVA, op. cit., p. 49.

${ }^{65}$ SILVA, op. cit., p. 28.

${ }^{66}$ Ibidem.
} 
tem, por causa da importância que aqueles acontecimentos tiveram na vida do narrador" ${ }^{67}$.

Outro componente que demonstra o presente tópico é a dissertação de mestrado produzida por um docente da universidade, Jorge Cernev ${ }^{68}$ - que ingressou como professor do curso de História na FEFCLL em 1969-, intitulada Liberalismo e colonização: o caso do Norte do Paraná ${ }^{69}$. Nela, o autor

[...] não apenas reconheceu o papel da CTNP, no processo de colonização da região Norte do Paraná, como também referendou o próprio discurso da Companhia colonizadora de que suas atividades de colonização se deram dentro de uma perspectiva liberal, porém objetivando o bem estar social das comunidades em que ela esteve inserida. ${ }^{70}$

Escrito de uma perspectiva weberiana, defendendo que “[...] a ética protestante seria a base para o êxito dos empreendimentos liberais na região"71, o texto de Cernev demonstra "[...] não ter havido diferenças significativas entre a escrita acadêmica da história e o memorialismo oficial, havendo certa homogeneidade discursiva entre ambos"72.

Em síntese, a formação acadêmica, por si só, não representou uma ruptura ou a autonomização do campo historiográfico. Os casos citados, dos docentes Conceição Aparecida Duarte Geraldo, Maria Dulce Alho Gotti e Jorge Cernev, demonstram isso, além de exemplificarem a assimilação e a ampliação do poder do antigo campo.

3) O campo de saber nominado "historiográfico" não estaria restrito ao âmbito da instituição universitária e, por conseguinte, o saber que o constitui não se limitaria aos "especialistas" da área. De acordo com Bourdieu, no campo

${ }^{67}$ POLLAK, Michael. Memória e identidade social. Revista Estudos Históricos, Rio de Janeiro: FGV, v. 5, n. 10, p. 200-212, 1992 apud SILVA, op. cit., p. 28.

${ }^{68}$ Jorge Cernev é graduado em História pela Faculdade Estadual de Filosofia, Ciências e Letras de Londrina, no período de 1958-1962. Foi professor dessa mesma instituição, depois Universidade Estadual de Londrina, por 38 anos.

${ }^{69}$ CERNEV, Jorge. Liberalismo e colonização: o caso do Norte do Paraná. 1988. Dissertação (Mestrado em Filosofia) - Universidade Gama Filho, Rio de Janeiro (RJ), 1988.

${ }^{70}$ LEME, op. cit., p. 116.

${ }^{71}$ Jorge Cernev tem uma história de vida vinculada à região de Londrina, onde chegou com a família ainda na infância. Realizou seus estudos no colégio de tradição protestante nessa mesma cidade. Membro da Primeira Igreja Batista de Londrina, surgida em 1941, conviveu proximamente nesse ambiente com uma das personagens vinculadas à Companhia de Terras Norte do Paraná: Georg Craig Smith, também filiado à respectiva igreja. Tal aspecto possibilitou ao pesquisador melhor condição de acesso às fontes e às memórias sobre o passado da região sob o prisma do empreendimento colonizador inglês.

${ }^{72}$ ANDRÉ, op. cit., p. 74-75. 
os agentes "produzem, reproduzem ou difundem"73 bens simbólicos, na condição de especialistas ou não. Em sua obra A economia das trocas simbólicas ${ }^{74}$, ao tratar da gênese e estrutura do campo religioso, o autor exemplifica que não se pode criar uma dicotomia que separa produtores de bens religiosos entre especialistas e consumidores leigos, como se estes últimos fossem destituídos da capacidade de produzir eles mesmos os bens simbólicos que dão sentido à sua existência. Ou seja, os chamados "leigos" também são produtores coletivos dos referidos bens no campo.

Não há, portanto, uma produção de bens simbólicos ex-niilo pelos especialistas; existe, sim, da parte destes, apropriação ou mesmo expropriação dos frutos do trabalho daqueles primeiros agentes, para devolvê-los como um bem simbólico revestido de novas valorações, ou para atender a novas demandas: "[...] as significações [...] por eles [não-especialistas] produzidas ficam em estado bruto até que os especialistas trabalhem, lapidando-as para as apresentarem como se fossem uma intuição ou revelação original"75.

Sobre esse aspecto, em ensaio sobre "a prática histórica não acadêmica no Brasil"76, Malerba comenta que os "historiadores leigos", há muitas décadas, "[...] vêm tendo uma importante participação pública no Brasil", acrescentando que a história não se produz somente na academia: “[...] por suposto que temos seguro que se sempre produziu e ainda se produz historiografia fora dos circuitos acadêmicos" 77 .

Um exemplo dessa perspectiva é o livro do jornalista José Joffily, Londres-Londrina, lançado em 1984. Essa produção não ocorreu dentro do campo historiográfico universitário. É a primeira obra a se posicionar criticamente em relação às interpretações, então hegemônicas, que celebravam a CTNP como um modelo ideal de ocupação e de planejamento de um espaço rumo ao progresso e ao bem-estar social, a partir da iniciativa privada. No livro, o autor questiona o processo de vendas de terras do governo paranaense a um grupo britânico que, segundo ele, estava vinculado a um processo maior de relações entre o Brasil e a Inglaterra, e possuía ligação com empréstimos e

\footnotetext{
${ }^{73}$ BOURDIEU, 2003, op. cit., p. 20.

${ }^{74}$ BOURDIEU, Pierre. A economia das trocas simbólicas. São Paulo: Perspectiva, 1999.

${ }^{75}$ OLIVEIRA, Pedro A. Ribeiro. A teoria do trabalho religioso em Pierre Bourdieu. In: TEIXEIRA, Faustino (Org.). Sociologia da religião. Enfoques teóricos. Petrópolis: Vozes, 2003, p. 101.

${ }^{76}$ Título do capítulo: “Acadêmicos na berlinda ou: como cada um escreve a História? Uma reflexão sobre o embate entre historiadores acadêmicos e não acadêmicos no Brasil à luz dos embates sobre Public History”. In: MALERBA, 2018, op. cit., p. 123-157.
}

${ }^{77}$ Ibidem, p. 170. 
dívida externa. Reitera que "[...] o silêncio sobre a atuação do imperialismo inglês no Paraná não era ingênuo”.

A autêntica versão estava bloqueada pelo silêncio ou pela raridade de fontes idôneas. Assim, nas páginas da história do Paraná difundiu-se uma simpática imagem do imperialismo inglês. Seus agentes são saudados como salvadores do Brasil. Na retórica dos colonizadores, a cobiça - por mais desenfreada que seja - está invariavelmente mascarada pela abnegação, pela benemerência e pela filantropia. ${ }^{78}$

Quanto à metodologia e às fontes, o trabalho de Joffily apresenta um encaminhamento adensado em documentos e na crítica às publicações que tematizavam a região em estudo. $O$ autor faz um repasse investigativo dessas narrativas sobre o recente passado, as quais circulavam nos anos de 1950. Ao mencionar que fez a "leitura de mais de vinte compêndios didáticos", destaca "[...] que é mal contada a história do norte do Paraná, porque todos os autores partem de fontes destituídas de mínima isenção - as publicações da Companhia Melhoramentos Norte do Paraná"79. Ele afirma, também, que essa "[...] fonte de informação é tendenciosa, pelo seu próprio caráter promocional - Colonização e Desenvolvimento do Norte do Paraná -, editada pela Companhia loteadora das terras". Classifica tal obra como de "apologia e não de análise" ${ }^{80}$. Joffily menciona, ainda, que as produções, em geral, “[...] limitam-se a transcrever trechos daquele opúsculo comercial", ou a reproduzir o que circulava por meio dos três jornais existentes em Londrina no período: Paraná-Jornal; O Município; e Paraná Norte. O autor ressalta, sobre eles, que "[...] todos ostentavam páginas inteiras pagas pela Prefeitura ou por aquela Companhia"; o mesmo ocorre com "[...] as publicações, os periódicos e páginas avulsas - inclusive compêndios didáticos”" ${ }^{81}$. Ele conclui, por isso, que "[...] a autêntica versão estava bloqueada pelo silêncio ou pela raridade de fontes idôneas" $"$.

Além de diversos textos de jornais e de revistas, Joffily apresenta resultados de pesquisas em arquivos, bibliotecas, museus, bem como em cartas e ofícios de órgãos oficiais ligados à terra e à economia, contendo consultas que fez sobre dados referentes ao norte do Paraná ${ }^{83}$. Também realiza interlocução

\footnotetext{
${ }^{78}$ JOFFILY, José. Londres-Londrina. Rio de Janeiro: Paz e Terra, 1985, p. 31-32.

${ }^{79}$ Nome atribuído à Companhia de Terras Norte do Paraná a partir de 1951.

${ }^{80}$ JOFFILY, op. cit., p. 111.

${ }^{81}$ Ibidem.

${ }^{82}$ Ibidem, p. 31.

${ }^{83}$ Entre as páginas 139 e 257, o autor faz anexação de cópias de todos os documentos: cartas, ofícios, textos de jornais e de revistas, entre outros materiais que consultou para a elaboração do livro.
} 
com artigos de pesquisadores vinculados à universidade, como: Estudo, povoamento, crescimento e composição da população do norte novo do Paraná de 1940-1970, de Maria Adenir Peraro; Industrialização e pequenos empresários em Londrina, por Ana Cleide Chiarotti Cesário; e com dissertações e teses: 0 fenômeno urbano numa zona pioneira: Maringá, de autoria de France Luz ${ }^{84}$; Cafeicultura paranaense: 1900-1970, de Nadir A. Cancián ${ }^{85}$; A integração do índio na estrutura agrária do Paraná: o caso kaingáng, de Cecília Vieira Helm ${ }^{86}$.

No mais, destaca-se um olhar crítico de Joffily sobre os impactos ao meio ambiente ocasionados pelo processo de (re)ocupação pela empresa colonizadora da região norte paranaense, o que ele denomina "predatório desmatamento" 87 . Em síntese, o autor desenvolve uma crítica ao que chama de "mito da historiografia", marcado pela "propagação de equívocos [...], simplificações, conclusões generalizantes". Para tanto, propôs-se a fazer uma "discussão dos documentos arrolados", mais que apenas "mera constatação"88.

A historiadora Sonia Adum comenta que o livro de Joffily provocou grande debate ao revelar práticas de violência utilizadas, por exemplo, contra os índios coroados, justificadas para contemplar interesses da CTNP. O autor recebeu, por isso, pesadas críticas de pessoas identificadas com o campo do poder, com a visão memorialista da cidade, algumas, inclusive, mandaram cartas ao Departamento de História da Universidade Estadual de Londrina, reafirmando a versão de que não havia índios quando chegaram à região onde foi construída Londrina. Essas cartas solicitavam ao referido Departamento que se posicionasse publicamente sobre as críticas levantadas por Joffily e confirmasse, pois, a "verdadeira" e "única" história da colonização da região ${ }^{89}$.

4) As transformações no campo historiográfico seriam advindas dos programas de pós-graduação e de profissionalização da atividade acadêmica. A partir de meados dos anos de 1980, houve mudanças nas estruturas e nas regras da carreira dos professores universitários, passando-se a exigir, por exemplo, a titulação de mestrado e de doutorado.

\footnotetext{
${ }^{84}$ LUZ, France. 0 fenômeno urbano numa zoa pioneira: Maringá. 1980. Dissertação (Mestrado em História) Faculdade de Filosofia, Letras e Ciências Humanas, Universidade de São Paulo, São Paulo, 1980.

${ }^{85}$ CANCIÁN, Nadir A. Cafeicultura paranaense (1900-1970): estudo de conjuntura. 1977. Tese (Doutorado em História) - Departamento de História, Universidade de São Paulo, São Paulo, 1977.

${ }^{86} \mathrm{HELM}$, Cecília Vieira. A integração do índio na estrutura agrária do Paraná: o caso kaingáng. 1974. Tese (LivreDocência em Antropologia) - Universidade Federal do Paraná, Curitiba, 1974.

${ }^{87}$ JOFFILY, op. cit., p. 114.

${ }^{88}$ Ibidem, p. 33.

${ }^{89}$ ADUM, 2014, op. cit.
} 
Para três autores entrevistados, as exigências de titulação contidas nas novas regras da carreira profissional da universidade, a partir de meados dos anos de 1980, teria sido o principal motivo para o ingresso na pós-graduação, a fim de, assim, produzirem pesquisas com base no campo do saber historiográfico ${ }^{90}$. O deslocamento de docentes para outros centros de formação possibilitou o contato com novos elementos teóricos, metodológicos e temáticos. Os programas de pós-graduação fomentavam novas perspectivas historiográficas ${ }^{91}$, e a reverberação desses aportes contribuiria para a renovação do campo de atuação desses profissionais.

Egressos do próprio curso de História, com trajetória de vida vinculada à região, prosseguiram na carreira acadêmica em níveis de pós-graduação ${ }^{92}$. A produção e a atuação desses pesquisadores representariam significativas mudanças nas práticas teórico-metodológicas do Departamento de História, marcando um revisionismo da historiografia estabelecida no campo, pela "[...] exploração de territórios do conhecimento até então ignorados e silenciados", como destaca André, que atribui a essa mudança epistemológica influências recebidas de "[...] um marxismo renovado, as ideias de Foucault, as novas histórias cultural e política, entre outras possibilidades"93.

5) Haveria evidências de uma "conversão do olhar", parafraseando Bourdieu $^{94}$, de agentes e de setores inseridos no campo intelectual. Sonia Adum, uma das historiadoras inseridas no ambiente universitário aqui em

\footnotetext{
${ }^{90}$ Dedução extraída dos depoimentos de Nelson Dácio Tomazi (2012), Sônia Lopes Adum (2016) e José Miguel Arias Neto (2019). São três dos autores que, ao final dos anos de 1980 e início da década seguinte, produziram pesquisas e reflexões críticas àquela interpretação que compõe o campo de saber que denominamos "crônica". Entretanto, os motivos que os levaram a escolher o passado da cidade como tema de suas pesquisas escapam ao presente artigo e deverá ser objeto de outra abordagem.

${ }^{91}$ Nos casos aqui em análise, as seguintes universidades: USP, Unesp e UFPR.

${ }_{92}$ É o caso de Antonio Paulo Benatti, aluno do curso de graduação em História da UEL nos anos 1980. Posteriormente, ele produziu uma dissertação de mestrado em História, colocando "em xeque" o "ideário de uma cidade higiênica, ordeira e disciplinada". Descortinou, assim, as relações tensas entre grupos hegemônicos e marginais, os territórios e as personagens da prostituição da cidade de Londrina no auge da cafeicultura. Partindo da percepção de que a história das margens é fragmentada, uma vez que os indícios sobre o assunto são deixados, geralmente, por aqueles que detinham o monopólio do discurso, utilizou como fontes de investigação textos jornalísticos, literatura local sobre Londrina e fontes orais. Cf. BENATTI, Antonio Paulo. 0 centro e as margens: boemia e prostituição na "capital mundial do café" (Londrina: 1930-1970). 1996. Dissertação (Mestrado em História) - Universidade Federal do Paraná, Curitiba, 1996.

${ }^{93}$ ANDRÉ, op. cit., p. 76.

${ }^{94}$ Pierre Bourdieu usa a expressão "conversão do olhar" para definir a ruptura epistemológica "[...] com o campo de certezas partilhadas que fundamenta a comum opinião dos doutores". Trata-se de produzir um novo olhar sobre ou a partir do campo; uma mudança de visão; uma reorientação intelectual. Cf. BOURDIEU, Pierre. O poder simbólico. Lisboa: DIFEL, 1989, p. 39; BOURDIEU, Pierre. Esboço de auto-análise. São Paulo: Companhia das Letras, 2005, p. 86-88.
} 
análise, representa um dos momentos da ruptura com o campo anterior. Ela teve sua formação na antiga Faculdade, onde ingressou em 1973 como aluna, portanto, pertencente ao campo "crônica": "Fui aluna de um curso de perfil tradicional, durante a graduação; em seguida, passei a trabalhar como docente na UEL. Depois fui fazer o mestrado em uma instituição com produção marcada pela presença de doutores"95.

Ademais, ela associa sua mudança de olhar historiográfico às disputas de poder dentro da cidade ${ }^{96} \mathrm{e}$ às novas regras do campo universitário ${ }^{97}$. Durante o mestrado ${ }^{98}$, novas leituras historiográficas possibilitaram conceber o passado sob outra visão epistemológica. Destaca, ainda, que surgiam estudos sobre os "excluídos" em geral; sendo assim, o olhar etnológico descobria "o outro":

Na busca pelos processos criminais, segui a influência da historiografia no momento, a história a contrapelo, do olhar a partir dos vencidos e não dos vencedores, da história vista de baixo; fazer a história do outro, isso era muito marcado no momento. ${ }^{99}$

A autora questionou as lógicas de poder presentes no memorialismo: "Eu passei a fazer uma leitura crítica dessa abordagem sobre o passado, perguntando: de onde ela emerge? De onde vem essa visão?"100

Analisei como a ideologia estadonovista de pátria como família se reproduziu no microcosmo dos anos 1930, em Londrina, na ideia de "família pioneira da Companhia de Terras Norte do Paraná". Nesse emaranhado ideológico, destaquei a presença do "outro", representado por aqueles que, vindo em busca do paraíso, não conseguiram fazer parte da "família", transformando-se em ladrões, malandros, mendigos, curandeiros, prostitutas etc., compondo assim o quadro da barbárie. ${ }^{101}$

\footnotetext{
${ }^{95}$ ADUM, 2014, op. cit.

${ }^{96}$ Viveu em Londrina desde a infância, podendo, assim, observar "[...] o progresso e a riqueza de famílias economicamente bem sucedidas e, no entorno, a circulação de pessoas envolvidas com a prostituição, a violência, alvos da ação policial” (ADUM, 2014, op. cit.).

${ }^{97}$ Adum relata sua experiência: "Entrei para dar aulas na UEL como convidada, não por concurso; fui convidada para substituir uma professora. Naquele tempo não havia concurso; depois de um tempo o docente era automaticamente efetivado na função. Houve mudanças institucionais. Passamos a pensar na carreira. Vários docentes do departamento de História decidiram fazer o mestrado" (ADUM, 2014, op. cit.).

${ }^{98}$ ADUM, Sonia Maria S. Lopes. Imagens do progresso: civilização e barbárie em Londrina (1930-1960). 1991. Dissertação (Mestrado em História) - Universidade Estadual Paulista, Assis, 1991.

${ }^{99}$ ADUM, 2014, op. cit.

${ }^{100}$ Ibidem.

${ }^{101}$ ADUM, 2008, op. cit., p. 17-18.
} 
Arias Neto, historiador também inserido nesse ambiente - inicialmente como aluno do curso de História da UEL, nos anos 1980, depois como docente da respectiva instituição -, teria vivenciado um cenário de ruptura. Ele comenta que, quando realizou seu mestrado, “[...] as fontes estavam no $\mathrm{CDPH}^{102}$, museu, biblioteca pública; mas ao trabalhar com objeto regional, em temporalidade recente, percebe-se que muitas coisas não estão nas fontes escritas". E acrescenta:

Daí o papel das fontes orais na maneira de se abordar o objeto: a riqueza dos depoimentos de personagens que vivenciaram esse passado, de quem é parte desse passado. Usei os depoimentos orais nas linhas de trabalho, como diretrizes que serão preenchidas com outra documentação, as fontes escritas. Aquilo que os "pioneiros" me disseram apontava o caminho a ser trilhado, a ser problematizado. ${ }^{103}$

Arias Neto coloca, também, que houve mudança no Arquivo da Universidade: “[...] quando eu comecei a fazer o mestrado, o CDPH começava a ser aberto para outras perspectivas, por influência dos novos docentes"104, os quais decidiram não mais manter o acervo "[...] apenas como depósito, como queria a velha geração. 0 Arquivo estava sendo transformado em Centro de Documentação e Pesquisa Histórica e começava a ser conceitualmente renovado" ${ }^{105}$. Tal aspecto é detalhado por Leme:

O CDPH, por sua vinculação administrativa e acadêmica com o Departamento de História, caminhou dentro de uma política de formação de um acervo mais plural, contemplando um universo mais diverso de enfoques, de novos sujeitos, o que significou uma abertura para a entrada de coleções e fundos documentais, como autos criminais, fanzines, coleções sobre diferentes temáticas: movimentos estudantil, operário, agrário, partidos políticos, religiões, imigração, dentre outros. ${ }^{106}$

Essa "conversão do olhar" conceitual possibilitava, então, enxergar, “[...] no cenário da história local, novos temas e personagens até então

\footnotetext{
${ }^{102} \mathrm{CDPH}$ - Centro de Documentação e Pesquisa em História, do Departamento de História da Universidade Estadual de Londrina. Atualmente, denominado NDPH - Núcleo de Documentação e Pesquisa em História.

${ }^{103}$ ARIAS NETO, José Miguel. Entrevista concedida a Gilmar Arruda e Wander de Lara de Proença. Projeto de pesquisa intitulado: "A historiografia no Paraná (1970-2012) - os historiadores, seus lugares e suas regiões". Londrina, UEL, 2019.

${ }^{104}$ Esses novos docentes que passaram a compor o Departamento de História, nos anos de 1980, desenvolviam pesquisas sobre temáticas que espelhavam novas tendências historiográficas no período, tais como: história ambiental, urbanização, história e memória, história e ficção, história e cinema, nova história política, algumas com enfoques regionais.

${ }^{105}$ ARIAS NETO, op. cit.

${ }^{106}$ LEME, op. cit., p. 170.
} 
esquecidos ou simplesmente silenciados"107. A mesma "conversão" de Sonia Adum, as mudanças em relação às fontes, o surgimento do CDPH são evidências de tensões e de rupturas com o campo da crônica dentro da instituição universitária. Seria o tempo da "historiografia".

\section{Considerações finais}

Ao final da análise desenvolvida, podem ser apontados alguns tópicos como principais conclusões.

1) O campo da "crônica" continua influente na produção de saberes sobre o passado na fronteira, mesmo após décadas de críticas recebidas. "A história tradicional sempre esteve sob constante vigilância por parte daqueles que se consideram donos da memória" ${ }^{108}$. Um espaço que visibiliza essa perspectiva é o Museu Histórico da cidade que, conforme observa Tomazi, “[...] representa a continuidade da visão tradicional, visto que a crítica não foi ali incorporada. Continua sendo um altar de culto à memória dos vencedores, dos que promoveram a 'civilização e o progresso' no norte paranaense”109.

Faz-se notório, nesse espaço, o inquietante silêncio em relação à memória de indígenas, afrodescendentes, trabalhadores rurais posseiros e inúmeros outros personagens que marcam a história da região em análise. São, portanto, evidências que comprovam a hipótese apresentada ao longo deste artigo: o campo da "crônica" ampliou seu poder, seu espaço e sua representatividade por meio da assimilação das regras e pelo aval do campo historiográfico universitário.

2) O campo de saber sobre o passado no âmbito da universidade integra ou é constituído, também, pelas produções da "crônica". Em princípio, concebe-se que a História como disciplina acadêmica funciona como um campo que tem a garantia de certa autonomia, “[...] a qual supõe a delimitação de fronteiras, a ruptura com interesses exteriores, a constituição de desafios internos, a existência de um elenco de profissionais dedicados ao tratamento de objetos próprios ${ }^{110}$.

Entretanto, essa autonomia é fundamentalmente ambígua, pois lhe é conexa a "retórica do corte falso" que, a partir de Bourdieu, significa

\footnotetext{
${ }^{107}$ Ibidem.

${ }^{108}$ ADUM, 2014, op. cit.

${ }^{109}$ TOMAZI, Nelson Dácio. Entrevista concedida a Gilmar Arruda e Wander de Lara de Proença. Projeto de pesquisa intitulado: "A historiografia no Paraná (1970-2012) - os historiadores, seus lugares e suas regiões". Londrina, UEL, 2012.
}

${ }^{110}$ PINTO, op. cit., p. 82. 
“[...] a reinscrição de conteúdos profanos do campo sob as aparências de qualidade"111. Ou seja, a produção considerada "profana" costuma ser apropriada pelos "especialistas" e, uma vez lapidada, assume novas valorações, no campo intelectual, com o status científico.

O memorialismo tomado como fonte primária de dissertações e de teses evidencia que “[...] não nos é dado supor que partimos de um 'ponto zero', decretando a morte cívica de todo um elenco de pessoas que, em diversas gerações, e à luz delas, se voltaram a este ou aquele objeto que porventura nos interesse atualmente”. Pois, “[...] devido a uma característica básica do conhecimento histórico, que é sua própria historicidade, temos que nos haver com todas as contribuições dos que nos antecederam"112.

Assim, os saberes sobre o passado que subscrevem a saga de pioneiros e os interesses das elites de mando local, dos grupos econômicos ou das empresas colonizadoras são permanentemente revisitados pelas novas produções historiográficas: “[...] apesar de não serem trabalhos propriamente historiográficos, encontram-se na base da historiografia consagrada"; são fontes primárias, ainda que, para muitos que escreveram sobre a região, "confundiram-se com a própria historiografia"113.

3) Tem-se de considerar aspectos da "história da História", das análises que se encarregam de compreender as transformações no campo da produção do conhecimento histórico no Brasil na segunda metade do século XX. Em linhas gerais, aponta-se que o surgimento dos cursos superiores da disciplina de História e, posteriormente, a partir dos anos de 1970, a formalização da pós-graduação foram fatores fundamentais para as rupturas com a produção anterior, geralmente denominada metódica, memorialista ou cronista, conforme

\footnotetext{
${ }^{111}$ Ibidem.

${ }^{112}$ MALERBA, Jurandir. Em busca de um conceito de historiografia: elementos para uma discussão. Varia Historia, Ouro Preto, n. 27, p. 27-47, 2002, p. 36-37.

${ }^{113}$ ADUM, 2008. op. cit., p. 4.
} 


\title{
observado nos textos de Falcon ${ }^{114}$, Fico e Polito ${ }^{115}$, Malerba ${ }^{116}$, Machado ${ }^{117}$, Marchi et al. ${ }^{118}$, entre outros ${ }^{119}$.
}

\begin{abstract}
${ }^{114}$ Falcon comenta que a oposição entre tradição e inovação produziu conflitos crescentes no campo historiográfico brasileiro, confrontando teorização versus empirismo. Ele destaca que esse binômio "[...] foi muito importante, especialmente nos anos 1960 e 70, para algumas tomadas de consciência a propósito das diferenças entre a forma tradicional e a forma nova de se conceber a natureza do ofício do historiador e o próprio ensino da História". Acrescenta, ainda, que "[...] é possível afirmar que a oposição e conflito entre historiadores/docentes de tradição empirista e aqueles dentre seus colegas que preconizavam uma concepção nova de História agravou-se sobremaneira nos anos 1970". Conclui afirmando que "[...] até os começos dos anos 1980 ainda era viável opor dois tipos ou duas identidades de historiadores - o tipo tradicional e o tipo moderno ou inovador" (FALCON, Francisco J. C. A identidade do historiador. Estudos Históricos, Rio de Janeiro, v. 9, n. 17, 1996, p. 9, 10 e 12, grifos nossos).
\end{abstract}

${ }^{115}$ Carlos Fico e Ronald Polito consideram que, para uma compreensão do estágio atual da historiografia brasileira, "[...] é essencial uma referência à evolução das universidades do país ou, mais especificamente, dos cursos de pós-graduação em história brasileiros". Isso porque "[...] a quase totalidade da produção historiográfica brasileira efetiva-se nestes cursos (através da produção de teses de doutoramento e de dissertações de mestrado) ou em torno deles (com os trabalhos gerados pelos professores que neles atuam)." (FICO; POLITO, op. cit., p. 142). Ou seja, seria próprio da história da historiografia concentrar sua análise no ambiente universitário; entretanto, no caso do campo histórico surgido em Londrina, nota-se que é também preponderante considerar o espaço da crônica.

${ }^{116}$ Malerba situa a década de 1960 como referência de uma "transição paradigmática" das transformações historiográficas no Brasil: "[...] marcada por uma violenta aceleração do tempo histórico, que incidiu nas formas do ser, mas também do fazer e do pensar históricos" (MALERBA, 2009, op. cit., p. 19). Também, ao refletir sobre o conceito de "história pública", o autor expõe a composição que polariza os "historiadores práticos" ou "leigos" - sem a formação específica no campo historiográfico - e os historiadores "acadêmicos" - treinados na reflexão histórica para pesquisa documental, com análise teórica e metodologicamente embasada. Ele considera haver um “[...] embate entre historiadores acadêmicos e não acadêmicos". Destaca ainda que, entre meados dos anos 1980 e 1990, "[...] a historiografia brasileira transformou-se rapidamente numa disciplina acadêmica totalmente institucionalizada dentro de um sistema universitário", buscando, com isso, uma demarcação que separava os saberes acadêmicos e aquele dos "leigos" (MALERBA, 2018, op. cit., p. 57, 111, 123, grifos nossos).

${ }^{117}$ Daiane Machado, ao abordar a criação do curso de História na UFPR, em 1959, aponta que, de imediato, buscou-se ali uma ruptura entre a historiografia a ser produzida e os saberes já existentes sobre o passado paranaense. Uma das primeiras ações daquele Departamento foi realizar "[...] uma análise revisionista de obras sobre o Paraná, produzidas fora da academia", com levantamento "[...] dos problemas que nela restam por serem equacionados e resolvidos" (MACHADO, Daiane Vaiz. Modo de ser historiadora: Cecília Westphalen no campo historiográfico brasileiro da segunda metade do século XX. História da historiografia, Ouro Preto, n. 22, p. 134-151, p. 138-139, dez. 2016, grifo nosso).

${ }^{118}$ Também Euclides Marchi, Maria Ignês M. de Boni, Márcia Siqueira e Sérgio Nadalin apresentam uma avaliação dos 30 anos de produção do Departamento de História da UFPR, destacando que o Mestrado, implantado na década de 1970, teria absorvido mudanças do debate historiográfico que "[...] trazia à tona novas questões que passariam a interferir no trabalho de produção de História", provocando "[...] uma renovação na historiografia paranaense", fazendo com que vários professores passassem a orientar suas pesquisas "com outros quadros conceituais", redefinindo o perfil historiográfico do Departamento. 0 que se constata, entretanto, pelas fontes aqui exploradas, é que tal ruptura ou renovação mencionada pelos autores, no respectivo período, não se efetivou em regiões do interior, como Londrina. Cf. MARCHI, Euclides et al. Trinta anos de historiografia: um exercício de avaliação. Revista Brasileira de História, São Paulo, v. 13, n. 25-26, p. 133-142, set. 92/ago. 1993, p. 137.

${ }^{119}$ Apontam semelhante perspectiva as obras: DIEHL, Astor A. A cultura historiográfica brasileira: década de 1930 aos anos 1970. Passo Fundo: EDIUPF, 1999; DIEHL, Astor A. A cultura historiográfica nos anos 80: mudança 
A nossa pesquisa, porém, ao examinar detalhadamente um desses processos, o surgimento do novo campo em Londrina (PR) - com a presença dos cursos superiores (e a disciplina acadêmica), precursores da universidade -, demonstrou que a ruptura ou a tensão entre os dois campos de saber não ocorreu de pronto. Pelo contrário, o campo da "crônica" soube se apropriar das novas regras, assimilando-as e expandindo sua abrangência para a instituição "profissionalizante" das faculdades e, depois, universidade, mantendo as regras de poder já estabelecidas.

Não houve, pois, polarização entre os dois tipos de produção nem embate, mas teria sido uma ampliação do campo anterior, com intercâmbios recíprocos entre os saberes da academia e os da crônica. Nem mesmo a primeira geração de professores atuantes nos anos de 1970, já no âmbito da universidade, significou essa tensão. Somente na década de 1980 apareceram os movimentos de tensão e de ruptura, conflitos da dinamicidade do próprio campo, possibilitando mudanças.

Dentre outros aspectos, teria contribuído para essa composição amistosa a influência exercida por um contexto mais amplo de poder: a ditadura militar no Brasil. Falcon observa que seu clima autoritário e repressivo teria beneficiado a "concepção tradicional de história", geralmente "aliada do poder"120.

As instituições de ensino superior de Londrina se estabeleceram nesse período do regime militar, estando, por isso, sujeitas a formas de vigilância: a cidade, "[...] por sua importância econômica e estratégica no Paraná, passou a receber uma atenção especial dos órgãos federais de informação e de controle $^{121}$. A História, portanto, em seu âmbito disciplinar, pode ter sofrido influências desse mecanismo, aproximando-se estrategicamente do campo do poder, atenuando possíveis tensões com as elites de mando local.

A história da historiografia também evidencia outras perspectivas em relação aos grandes modelos explicativos, por vezes tomados como válidos para a realidade brasileira, em geral. A "desmetropolização"122 da produção historiográfica aponta que, na cidade de fronteira aqui em análise, os modos e os lugares de produção fogem àqueles paradigmas situados em polos historiográficos, sobretudo da região sudeste, que "imperam como historiografias

estrutural na matriz historiográfica brasileira. Porto Alegre: Evangraf, 1993; BURMESTER, Ana Maria de O. A (des)construção do discurso histórico: a historiografia brasileira dos anos 70. Curitiba: Aos Quatro Ventos, 1997.

${ }^{120} \mathrm{O}$ autor comenta que, nos anos 1960 e 1970, as formas “[...] de se conceber a natureza do ofício do historiador e o próprio ensino da História" eram marcadas pelo "[...] fogo cruzado das pressões político-ideológicas autoritárias" (FALCON, op. cit., p. 10).

${ }^{121}$ LEME, op. cit., p. 166.

${ }^{122}$ FICO; POLITO, op. cit., p. 142. 
nacionais", como "[...] um colégio invisível que norteou nessas últimas três décadas como deveria ser produzida a história no país", estabelecendo, assim, "[...] a construção da imagem e da memória do campo disciplinar no Brasil". Portanto, os estudos pontuais podem contribuir para promover revisões das regras gerais ${ }^{123}$.

4) Ainda que a historiografia no âmbito do curso universitário, por longo período, tenha conceitualmente legitimado a produção do campo da "crônica" - e continue, em parte, a fazê-lo -, foi no âmbito da universidade que essa visão sobre o passado na fronteira veio a ser problematizada de forma mais contundente. Os materiais memorialísticos revisitados como fontes possibilitaram que o passado já estabelecido como "verdade" passasse a ser exposto ao elemento da dúvida pelo olhar crítico e investigativo da historiografia, sob influência das novas conquistas epistemológicas, enriquecendo o debate acadêmico da historiografia sobre a região: "Ao revelarem outras possibilidades de narrativas do passado local, essas pesquisas acabaram por fragilizar e colocar na berlinda a perspectiva de história, então consolidada e hegemônica na cidade"124.

À título de finalização, cabem as perguntas: por que teria surgido um questionamento às narrativas da "crônica" histórica sobre o passado da região? Seria a crise de identidade dos agentes envolvidos? Seriam as geadas que dizimaram os sonhos do "ouro verde" cafeeiro, sobretudo a de 1975, por seu alcance e seu impacto? Ou ainda, a mudança do perfil populacional? Estaríamos diante de mudanças impulsionadas por alterações internas no campo da historiografia? As respostas a essas questões excedem os limites deste texto, ficando como hipóteses ou objeto para outro artigo.

Por ora, um vetor preponderante pode ser apontado: a presença do campo intelectual ou acadêmico na fronteira não tensionou de imediato as redes de poder e, por mais de duas décadas, não promoveu embates em torno da memória. Entretanto, foi a universidade que possibilitou o alargamento do campo e seu respectivo espaço para a crítica; representou a possibilidade da dúvida, do pensamento diverso, da produção de novos bens simbólicos a

\footnotetext{
${ }^{123}$ Aspectos destacados na apresentação da obra coletiva, organizada por Santos e Spíndola. Em linhas gerais, os autores chamam a atenção para a necessidade de um olhar para outras regiões, nas quais a historiografia em seu percurso buscou outras veredas. O texto também denuncia uma hegemonia de produção polarizada entre paulistas - representada por USP, Unicamp - e fluminenses - tanto instituições de ensino quanto entidades ou revistas especializadas (SANTOS, Wagner Germiniano dos; SPÍNDOLA, Pablo (Orgs.). Teoria da história e história da historiografia. Ensaios. Jundiaí-SP: Paco Editorial, 2019).
}

${ }^{124}$ ANDRÉ, op. cit., p. 25. 
partir de usos do passado, com fontes e metodologia, acumulando um capital valorativo da disciplina historiográfica.

Daí o exemplo de uma obra, produzida fora do âmbito universitário, de José Joffily, apontar para esse locus como sua referência mais ambiciosa em busca de ressonância da perspectiva crítica que apresentou sobre o passado na fronteira: “[...] sem aspas, sem facciosismo, sem receio de levá-la à Universidade" ${ }^{125}$.

Artigo recebido para publicação em 19/09/2019 Artigo aprovado para publicação em 25/05/2020

${ }^{125}$ JOFFILY, op. cit., p. 114. 